УДК 63.Г.43.004.12/.582(477 41)

(C) 2016

Примак І. Д., доктор сільськогосподарських наук, Панченко О. Б., аспірант

(науковий керівник - доктор сільськогосподарських наук I. Д. Примак)

Білоцерківський національний аграрний університет

\title{
СТРУКТУРНИЙ СТАН І БУДОВА ОРНОГО ШАРУ ЧОРНОЗЕМУ ТИПОВОГО ЗА РІЗНИХ СИСТЕМ ОСНОВНОГО ОБРОБІТКУ І УДОБРЕННЯ В СПЕЦІАЛІЗОВАНІЙ ЗЕРНОПРОСАПНІЙ СІВОЗМІНІ ЦЕНТРАЛЬНОГО ЛІСОСТЕПУ УКРАЇНИ
}

\section{Рецензент - доктор сільськогосподарських наук А. П. Стадник}

Висвітлено вплив довготривалої дії різних систем основного обробітку трунту $і$ удобрення на зміну агрофізичних властивостей чорнозему типового $і$ продуктивності спеціалізованої польової n'ятипільної сівозміни. На чорноземах типових Центрального Ліcoстепу України кращі агрофізичні показники родючості орного шару трунту спостерігаються за трирічного застосування тривалого мілкого обробітку, порівняно з безполицевим і тривалим полицевим обробітком. У n'ятипільній зернопросапній сівозміні рекомендується глибока (на 25-27 см) культурна оранка в одному полі (де вноситься гній), а на решті полів - мілкий обробіток на 10-12 см.

Ключові слова: обробіток, добрива, трунт, структура, щиільність, пористість, продукmивність.

Постановка проблеми. У XXI ст. швидко зростає енергоозброєність рільництва, що надає практично необмежені можливості в інтенсивності і поглибленні обробітку грунту. Проте досвід і практика свідчать, що в багатьох випадках зростання інтенсивності обробітку грунту все частіше призводить до негативних наслідків: зростають затрати на його виконання, урожайність не підвищується, прискорюється мінералізація гумусу, грунт розпилюється, зменшується його стійкість проти ерозії.

Відомо, що багаторазові проходи по полю тракторів і грунтообробних знарядь призводять до переущільнення грунту, що негативно впливає на якості наступних обробітків та врожайності сільськогосподарських культур. 3 другої половини $\mathrm{XX}$ ст. розпочався різкий поворот від практики багаторазових проходів рільничної техніки до їх скорочення або й повної відмови від механічних обробітків.

Теоретичною основою мінімізації обробітку служать досягнення в області агрофізики грунту, зокрема вчення про рівноважну i оптимальну щільність грунту $[6,7,8]$.
Аналіз останніх досліджень і публікацій, у яких започатковано розв'язання проблеми. Позитивний вплив мінімізації обробітку на родючість грунту сьогодні ні в кого не викликає сумніву. Завдання полягає у встановленні оптимального ступеня його інтенсивності в конкретних грунтово-кліматичних умовах [1].

Механічний обробіток, як відомо, впливає на умови вирощування рослин, у першу чергу, через зміну будови грунту. Тому необхідні глибокі знання показників оптимальної будови і агрофізичної суті кожного заходу і знаряддя обробітку, а також чітка уява, за рахунок яких основних змін у будові орного шару забезпечується позитивний вплив механічного обробітку на умови вирощування рослин. Тільки за цього можливий подальший розвиток теоретичних і практичних основ обробітку грунту. Порівнюючи оптимальні значення 3 фактичними на даний момент у польових умовах, а за необхідності і з агрофізичними характеристиками грунтообробних знарядь, створюється можливість обрати раціональні способи, заходи, глибину і знаряддя обробітку грунту, або їх найбільш ефективне поєднання, тобто систему обробітку. Проте вплив будови грунту на умови життя рослин настільки багатогранний і складний, що визначити ці параметри нелегко. Провідне місце у фізиці грунту займає вивчення його щільності, яка залежить, перш за все, від гранулометричного складу і структурного стану грунту та технології вирощування культур.

Досліджень 3 вивчення прямого впливу різної оструктуреності грунту на врожайність польових культур було не так вже й багато, а їх результати не завжди підтверджували прямий зв'язок між структурою і родючістю грунту.

Проте, якщо врахувати, що оструктурені грунти не запливають, довше зберігають надану обробітком будову, не переущільнюються, потребують менших тяглових зусиль на обробіток, 


\section{СІЛЬСЬКЕ ГОСПОДАРСТВО. РОСЛИННИЦТВО}

більш стійкі до водної та вітрової ерозії, то стане зрозумілим, що хоч структура і родючість не тотожні, але між ними існує тісна залежність.

У дослідах Білоцерківського НАУ [9] на чорноземі типовому малогумусному легкосуглинковому в середньому за п'ять років на дату сівби культур зернопросапної сівозміни вміст водотривких агрегатів дещо вищий за різноглибинної оранки, ніж постійного обробітку плоскорізом i дисковою бороною.

Покращання структури верхніх шарів грунту за мінімального обробітку М. К. Шикула, Г. В. Назаренко [10] пояснюють насамперед поверхневим загортанням органічних добрив і накопиченням в орному шарі значної кількості рослинних решток. Переважна більшість вчених вказує на несуттєвий вплив глибини і способів обробітку на структурно-агрегатний стан орного шару $[1,2,3]$.

Поява в шарі грунту 10-20 см ущільненого прошарку за тривалого (5-12 років) мінімального обробітку чорнозему типового в дослідах М. К. Шикули, Г. В. Назаренка не було перешкодою для отримання більш високих урожаїв кращої якості [10].

Багато вчених вказують на несуттєвий вплив глибини і способів обробітку на щільність орного шару грунту $[1,4,8]$.

Мета досліджень - встановити найбільш ефективну систему механічного обробітку грунту за різних рівнів удобрення в зернопросапній сівозміні, яка забезпечує її продуктивність на рівні 75-80 ц/га сухої речовини за одночасного високого протибур'янового ефекту.

Завдання досліджень полягали у вивченні впливу різних систем основного обробітку грунту i удобрення на зміну структурного стану, щільності будови, капілярної і некапілярної пористості орного шару чорнозему типового та продуктивності спеціалізованої сівозміни.

Методика досліджень. Дослідження проводили впродовж 2013-2015 рр. у стаціонарному польовому досліді на дослідному полі Білоцерківського НАУ. Грунт - чорнозем типовий глибокий малогумусний легкосуглинковий. Повторність досліду - триразова, площа облікової ділянки $-112 \mathrm{~m}^{2}$.

У сівозміні досліджували чотири варіанти основного обробітку (табл. 1) і чотири системи удобрення. Норми щорічного внесення добрив на 1 га сівозміни становили: без добрив (контроль), перший рівень -4 т гною $+\mathrm{N}_{26} \mathrm{P}_{44} \mathrm{~K}_{44}$, другий -8 т гною $+\mathrm{N}_{58} \mathrm{P}_{80} \mathrm{~K}_{80}$, третій -12 т гною + $\mathrm{N}_{83} \mathrm{P}_{116} \mathrm{~K}_{116}$.

Оранку на глибину $16-18,20-22$ і $25-27$ см здійснювали плугом ПЛН 3-35, мілкий обробіток на 10-12 см - важкою дисковою бороною БДВ3,0 , плоскорізний (безполицевий) обробіток плоскорізом КПГ-250. 3 органічних добрив вносили напівперепрілий гній великої рогатої худоби на солом'яній підстилці, з мінеральних - аміачну селітру, простий гранульований суперфосфат і калійну сіль.

Потенційну забур'яненість визначали методом відмивання мулистої фракції на ситах 3 діаметром отворів 0,25 мм, а актуальну - кількісноваговим методом.

Водотривкість структури грунту визначали методом I. М. Бакшеєва, а будову - методом насичення грунтового зразку водою в циліндрах [3].

\section{1. Схема обробітку грунту під культури сівозміни}

\begin{tabular}{|c|c|c|c|c|c|}
\hline \multirow{3}{*}{$\begin{array}{c}\text { № } \\
\text { поля }\end{array}$} & \multirow{3}{*}{ Культура-сівозміна } & \multicolumn{4}{|c|}{ Варіанти обробітку грунту } \\
\hline & & $\begin{array}{c}1 \\
\text { (тривалий } \\
\text { полицевий, } \\
\text { контроль) }\end{array}$ & $\begin{array}{c}2 \\
\text { (безполице- } \\
\text { вий, плоско- } \\
\text { різний) }\end{array}$ & $\begin{array}{c}3 \\
\text { (диференці- } \\
\text { йований) }\end{array}$ & $\begin{array}{c}4 \\
\text { (тривалий } \\
\text { мілкий) }\end{array}$ \\
\hline & & \multicolumn{4}{|c|}{ Глибина (см) і знаряддя обробітку } \\
\hline 1 & Горох & 16-18 (о.) & 16-18 (пл.) & 16-18 (о.) & 10-12 (д.б.) \\
\hline 2 & Пшениця озима & 10-12 (д.б.) & 10-12 (д.б.) & 10-12 (д.б.) & 10-12 (д.б.) \\
\hline 3 & Гречка & $16-18$ (o.) & 16-18 (пл.) & 16-18 (пл.) & 10-12 (д.б.) \\
\hline 4 & Кукурудза на зерно & $25-27$ (o.) & 25-27 (пл.) & $25-27$ (о.) & $25-27$ (о.) \\
\hline 5 & Ячмінь ярий & $20-22$ (о.) & 20-22 (пл.) & 20-22 (п.л) & 10-12 (д.б.) \\
\hline
\end{tabular}

Примітка: о - оранка; пл. - обробіток плоскорізом; д.б. - обробіток дисковою бороною. 


\section{СІЛЬСЬКЕ ГОСПОДАРСТВО. РОСЛИННИЦТВО}

Результати досліджень. Дослідженнями встановлено, що структурний стан орного шару помітно не відрізняється на першому і третьому варіантах обробітку грунту.

Вміст водотривких агрегатів під час сівби $\mathrm{i}$ збирання врожаю за тривалого полицевого обробітку становив відповідно 58,7 і 63,0 \%, а за диференційованого - 59,5 і 163,7 \% (табл. 2).

Постійний плоскорізний обробіток, порівняно 3 контролем, спричинив зменшення вмісту агрономічно цінних водотривких агрегатів (розміром 0,25-10 мм) в орному шарі грунту під час сівби і збирання врожаю відповідно на 1,0 і 0,8 \%.

Найкращий структурний стан відмічений за тривалого мілкого обробітку, де виявлено в орному шарі 60,2 і 64,2 \% водотривких агрегатів, або на 1,5 і 1,2 \% більше, ніж на контролі.

Найбільш оструктуреною на всіх варіантах досліду виявляється нижня частина (20-30 см) орного шару, водночас більш помітна різниця за вмістом агрономічно цінних агрегатів між нижньою і верхньою частинами орного шару грунту спостерігається за мілкого і особливо безполицевого обробітку. Різниця в оструктуреності нижньої і верхньої частин орного шару грунту на дату сівби і збирання врожаю становила відповід- но: на першому варіанті обробітку - 2,9 і 4,3 \%, другому - 8,0 і 8,8 \%, третьому - 4,5 і 6,4 \%, четвертому $-6,5$ і 8,7 \%.

Зростання кількості водотривких агрегатів у нижній частині орного шару, порівняно 3 верхньою, можна частково пояснити більшим ущільненням грунту, що забезпечує кращий контакт між частинками і більш сильне їх склеювання, а також майже повною відсутністю руйнівної дії на структурні агрегати сільськогосподарських машин, знарядь і атмосферних факторів.

Зменшення вмісту агрономічно цінних агрегатів у верхній частині орного шару грунту за плоскорізного обробітку, порівняно $з$ контролем, відбувалося в основному за рахунок утворення грудок понад 10 мм у діаметрі.

Кращий структурний стан нижньої частини орного шару за тривалого мілкого обробітку, порівняно 3 іншими варіантами, пояснюється, очевидно, майже повною відсутністю механічної дії на нього грунтообробних знарядь.

Так, уміст водотривких агрегатів у цій частині орного шару на дату сівби і збирання становив відповідно: на першому варіанті - 60,3 і 65,5\%, другому - 61,7 i 66,9 \%, третьому - 61,7 i 67,2 \%, четвертому - 63,4 і 69,2\%.

\section{2. Вміст водотривких атретатів в орному шарі трунту залежно від системи обробітку і удобрення, \%}

\begin{tabular}{|c|c|c|c|c|c|c|c|}
\hline \multirow{3}{*}{$\begin{array}{c}\text { Варіанти } \\
\text { обробітку } \\
\text { грунту }\end{array}$} & \multirow{3}{*}{$\begin{array}{l}\text { Рівні } \\
\text { удоб- } \\
\text { рення }\end{array}$} & \multicolumn{3}{|c|}{ Сівба } & \multicolumn{3}{|c|}{ Збирання } \\
\hline & & \multicolumn{6}{|c|}{ Шар грунту, см } \\
\hline & & $0-10$ & $10-20$ & $20-30$ & $0-10$ & $10-20$ & $20-30$ \\
\hline \multirow{4}{*}{$\begin{array}{c}1 \\
\text { (тривалий } \\
\text { полицевий, } \\
\text { контроль) }\end{array}$} & 0 & 52,4 & 53,2 & 55,3 & 57,2 & 58,9 & 62,4 \\
\hline & 1 & 55,3 & 56,5 & 58,2 & 59,1 & 60,1 & 63,6 \\
\hline & 2 & 58,8 & 60,4 & 62,3 & 63,3 & 64,0 & 67,2 \\
\hline & 3 & 62,9 & 63,5 & 65,4 & 65,3 & 66,1 & 68,8 \\
\hline \multirow{4}{*}{$\begin{array}{c}2 \\
\text { (безполи- } \\
\text { цевий) }\end{array}$} & 0 & 50,1 & 53,3 & 56,2 & 54,2 & 59,2 & 63,6 \\
\hline & 1 & 52,9 & 56,2 & 59,8 & 57,1 & 58,8 & 65,0 \\
\hline & 2 & 54,2 & 58,9 & 63,8 & 59,0 & 63,4 & 68,8 \\
\hline & 3 & 57,4 & 62,9 & 66,8 & 62,2 & 64,9 & 70,1 \\
\hline \multirow{4}{*}{$\begin{array}{c}3 \\
\text { (диферен- } \\
\text { ційований) }\end{array}$} & 0 & 52,2 & 53,8 & 56,4 & 56,8 & 58,8 & 64,7 \\
\hline & 1 & 54,7 & 57,2 & 60,2 & 58,0 & 61,8 & 65,8 \\
\hline & 2 & 59,0 & 61,9 & 63,4 & 62,8 & 65,1 & 68,7 \\
\hline & 3 & 63,2 & 64,7 & 66,8 & 65,7 & 67,0 & 69,5 \\
\hline \multirow{4}{*}{$\begin{array}{c}4 \\
\text { (тривалий } \\
\text { мілкий) }\end{array}$} & 0 & 52,4 & 54,2 & 57,5 & 57,0 & 58,4 & 66,4 \\
\hline & 1 & 53,9 & 58,7 & 62,5 & 57,9 & 61,8 & 66,7 \\
\hline & 2 & 58,6 & 62,7 & 65,8 & 62,3 & 64,8 & 70,0 \\
\hline & 3 & 62,8 & 65,3 & 67,7 & 64,8 & 66,9 & 73,5 \\
\hline
\end{tabular}




\section{СІЛЬСЬКЕ ГОСПОДАРСТВО. РОСЛИННИЦТВО}

Встановлено, що із підвищенням кількості внесених добрив оструктуреність грунту покращується. Так, за щорічного внесення на гектар ріллі сівозміни 4 т гною $+\mathrm{N}_{26} \mathrm{P}_{50} \mathrm{~K}_{50}, 8$ т гною + $\mathrm{N}_{58} \mathrm{P}_{80} \mathrm{~K}_{80}$ i 12 т гною $+\mathrm{N}_{83} \mathrm{P}_{116} \mathrm{~K}_{116}$ вміст водотривких агрегатів в орному шарі грунту на дату збирання врожаю підвищувався відповідно на 1,4; 5,3 i 7,2 \% за першого варіанту обробітку, 1,3; 4,7 i $6,7 \%$ - другого, 1,8; 5,4 i 7,3 \% - третього i 1,$5 ; 5,1$ та 7,8 \% - за четвертого, порівняно 3 неудобреними ділянками. Це пояснюється більш потужним розвитком кореневої системи культур, що надає дрібним грудочкам грунту водотривкої структури, а також зростанням площі листкової поверхні культур, яка захищає поверхню поля від руйнівної дії води і вітру. Чим потужніше розвинута коренева система рослин, тим рівномірніше пронизує вона шар грунту, і чим вища загальна іiі маса на одиницю об'єму грунту, тим менше залишається в грунті нерозчепленованих грудок і брил і тим менше в ньому тонких пилуватих мікроагрегатів, а отже, вищий коефіцієнт структурності [5]. Під час розкладання рослин- них решток утворюються гумусові речовини, вивільнюються пектини, пектозани, цукристі речовини і слизисті виділення грунтових мікроорганізмів, які надають водотривкості грунтовим агрегатам. Оструктуреність чорнозему під сільськогосподарськими культурами впродовж їх вегетації поліпшується в усіх частинах орного шару. Значно повніше стан грунту характеризує його будова, яка відіграє надзвичайно важливе значення в житті рослин, оскільки визначає середовище, де знаходиться вода, повітря, поживні речовини, мікроорганізми, коріння рослин.

Будова грунту характеризується багатьма показниками. Найбільш часто про будову грунту судять по його щільності, яка вимірюється об'ємною масою. Дослідженнями встановлено, що за безполицевого і диференційованого обробітку щільність будови орного шару грунту, порівняно 3 контролем, вища відповідно на 0,08 i

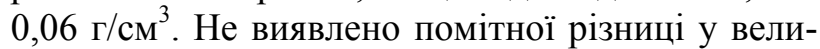
чині об'ємної маси орного шару чорнозему грунту за контрольного і тривалого мілкого обробіт-

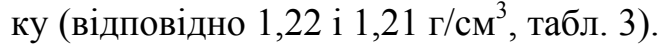

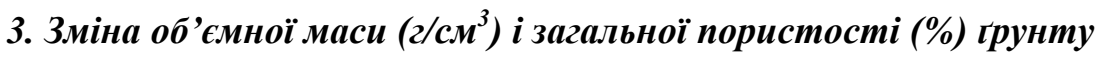 залежно від системи обробітку і удобрення}

\begin{tabular}{|c|c|c|c|c|c|c|c|c|c|c|}
\hline \multirow{3}{*}{$\begin{array}{c}\text { Варіанти } \\
\text { обробітку грунту }\end{array}$} & \multirow{3}{*}{$\begin{array}{c}\text { Рівні } \\
\text { удобрен- } \\
\text { ня }\end{array}$} & \multirow{3}{*}{$\begin{array}{c}\text { Об'ємна } \\
\text { маса (d) i } \\
\text { загальна } \\
\text { порис- } \\
\text { тість гру- } \\
\text { нту }\left(\mathrm{V}_{2}\right)\end{array}$} & \multicolumn{4}{|c|}{ Сівба } & \multicolumn{4}{|c|}{ Збирання } \\
\hline & & & \multicolumn{8}{|c|}{ Шар грунту, см } \\
\hline & & & $0-10$ & $10-20$ & $20-30$ & & $0-10$ & $10-20$ & $20-30$ & \\
\hline \multirow{4}{*}{$\begin{array}{c}1 \\
\text { (тривалий полице- } \\
\text { вий, контроль) }\end{array}$} & & $\mathrm{d}$ & 1,13 & 1,16 & 1,22 & 1,17 & 1,25 & 1,28 & 1,33 & 1,29 \\
\hline & & $\mathrm{V}_{2}$ & 56,4 & 52,2 & 48,2 & 52,3 & 52,2 & 51,1 & 48,4 & 50,6 \\
\hline & & $\mathrm{d}$ & 1,12 & 1,15 & 1,20 & 1,16 & 1,24 & 1,25 & 1,30 & 1,26 \\
\hline & & $\mathrm{V}_{2}$ & 58,3 & 53,4 & 49,2 & 53,7 & 54,5 & 52,1 & 46,9 & 51,9 \\
\hline \multirow{4}{*}{$\begin{array}{c}2 \\
\text { (безполицевий) }\end{array}$} & & $\mathrm{d}$ & 1,18 & 1,27 & 1,36 & 1,27 & 1,29 & 1,36 & 1,44 & 1,36 \\
\hline & & $\mathrm{V}_{2}$ & 55,3 & 50,8 & 42,2 & 49,5 & 50,5 & 46,2 & 40,1 & 45,6 \\
\hline & & $\mathrm{d}$ & 1,15 & 1,22 & 1,33 & 1,23 & 1,26 & 1,33 & 1,41 & 1,33 \\
\hline & & $\mathrm{V}_{2}$ & 57,1 & 51,7 & 43,4 & 50,7 & 53,6 & 47,3 & 42,4 & 47,8 \\
\hline \multirow{4}{*}{$\begin{array}{c}3 \\
\text { (диференційова- } \\
\text { ний) }\end{array}$} & \multirow{2}{*}{0} & $\mathrm{~d}$ & 1,14 & 1,25 & 1,35 & 1,25 & 1,25 & 1,33 & 1,40 & 1,33 \\
\hline & & $\mathrm{V}_{2}$ & 54,5 & 50,2 & 43,1 & 49,3 & 52,9 & 47,2 & 42,1 & 47,4 \\
\hline & & $\mathrm{d}$ & 1,13 & 1,22 & 1,33 & 1,23 & 1,23 & 1,31 & 1,39 & 1,31 \\
\hline & & $\mathrm{V}_{2}$ & 56,8 & 51,4 & 43,8 & 50,6 & 54,9 & 50,1 & 42,9 & 49,3 \\
\hline \multirow{4}{*}{$\begin{array}{c}4 \\
\text { (тривалий мілкий) }\end{array}$} & \multirow{2}{*}{0} & $\mathrm{~d}$ & 1,11 & 1,15 & 1,24 & 1,17 & 1,22 & 1,27 & 1,35 & 1,28 \\
\hline & & $\mathrm{V}_{2}$ & 57,2 & 53,5 & 48,6 & 53,1 & 54,0 & 52,2 & 47,8 & 51,4 \\
\hline & & $\mathrm{d}$ & 1,10 & 1,13 & 1,20 & 1,14 & 1,20 & 1,23 & 1,32 & 1,25 \\
\hline & & $\mathrm{V}_{2}$ & 58,8 & 55,2 & 49,4 & 54,4 & 56,2 & 53,3 & 47,6 & 52,4 \\
\hline
\end{tabular}


Ущільнення орного шару за плоскорізного i диференційованого обробітку відбувалося в основному за рахунок нижніх його частин (10-20, 20-30 см). Так, упродовж вегетації сільськогосподарських культур сівозміни об' ємна маса грунту в шарах 0-10, 10-20 і 20-30 см на першому варіанті обробітку становила відповідно 1,19; 1,21 і $1,26 r / \mathrm{cm}^{3}$, другому - 1,22; 1,30 i $1,39 \mathrm{r} / \mathrm{cm}^{3}$, третьому $-1,19 ; 1,28$ i $1,37 \mathrm{r} / \mathrm{cm}^{3}$, четвертому 1,$16 ; 1,20$ і 1,28 г/см ${ }^{3}$. Найбільш низький показник об'ємної маси верхнього (0-10 см) шару грунту $\left(1,16 \Gamma / \mathrm{cm}^{3}\right)$ відмічений у випадку тривалого мілкого обробітку.

Важливим показником будови грунту є величина порогового простору і співвідношення об'ємів пор різного розміру.

Показники загальної пористості орного шару грунту помітно не відрізнялись на ділянках тривалого полицевого і тривалого мілкого обробітку. На варіантах плоскорізного і диференційованого обробітку сумарний об'єм пор орного шару менший відповідно на 3,7 і 2,9\%, у порівнянні 3 контрольними ділянками (табл. 4).

Співвідношення капілярної до некапілярної пористості орного шару грунту на дату сівби i збирання врожаю становило відповідно: на пер- шому варіанті обробітку - 1,98 і 1,80, другому 2,29 i 1,62 , третьому - 2,14 i 1,91 , четвертому 1,91 i 1,49 .

На дату сівби капілярних проміжків в орному шарі грунту найбільше відмічено на четвертому $(36,2-37,1 \%)$, а найменше - на третьому $(32,6-$ $32,9 \%$ в варіанті обробітку. У день збирання врожаю об'єм капілярних пор орного шару грунту помітно не відрізняється на ділянках тривалого полицевого і тривалого мілкого обробітку. За плоскорізного i диференційованого обробітку капілярна пористість орного шару на дату збирання врожаю на 4,0-4,2 \% нижча, порівняно 3 контролем.

У наших дослідах не виявлено істотної різниці у величині аерації орного шару чорнозему по варіантах обробітку. Проте помітна різниця спостерігалась між контрольним, другим і третім варіантами обробітку в нижніх частинах орного шару.

Так, у шарах грунту 10-20 і 20-30 см некапілярна пористість на дату сівби становила: на першому варіанті - 16,5 і 15,9 \%, другому - 14,2 i $11,1 \%$, третьому - 16,1 і $11,8 \%$, четвертому 18,4 i $14,3 \%$.

\section{4. Зміна капілярної і некапілярної пористості (\%) трунту залежно від системи обробітку і удобрення}

\begin{tabular}{|c|c|c|c|c|c|c|c|c|}
\hline \multirow{3}{*}{$\begin{array}{c}\text { Варіанти } \\
\text { обробітку } \\
\text { грунту }\end{array}$} & \multirow{3}{*}{$\begin{array}{c}\text { Рівні } \\
\text { удобрення }\end{array}$} & \multirow{3}{*}{$\begin{array}{c}\text { Пористість: } \\
\text { капілярна } \\
\left(\mathrm{V}_{3}\right) \text { і некапі- } \\
\text { лярна }\left(\mathrm{V}_{4}\right)\end{array}$} & \multicolumn{3}{|c|}{ Сівба } & \multicolumn{3}{|c|}{ Збирання } \\
\hline & & & \multicolumn{6}{|c|}{ Шар грунту, см } \\
\hline & & & $0-10$ & $10-20$ & $20-30$ & $0-10$ & $10-20$ & $20-30$ \\
\hline \multirow{4}{*}{$\begin{array}{c}1 \\
\text { (тривалий } \\
\text { полицевий, } \\
\text { контроль) }\end{array}$} & \multirow{2}{*}{0} & $\mathrm{~V}_{3}$ & 35,4 & 35,4 & 32,4 & 32,3 & 31,8 & 33,1 \\
\hline & & $V_{4}$ & 21,0 & 16,8 & 15,8 & 19,9 & 19,3 & 15,3 \\
\hline & \multirow{2}{*}{3} & $\mathrm{~V}_{3}$ & 37,4 & 37,2 & 33,3 & 34,5 & 32,5 & 33,4 \\
\hline & & $\mathrm{V}_{4}$ & 20,9 & 16,2 & 15,9 & 20,0 & 19,6 & 15,5 \\
\hline \multirow{4}{*}{$\begin{array}{c}2 \\
\text { (безполицевий) }\end{array}$} & \multirow{2}{*}{0} & $\mathrm{~V}_{3}$ & 35,3 & 36,5 & 31,0 & 28,8 & 27,2 & 29,4 \\
\hline & & $\mathrm{V}_{4}$ & 20,0 & 14,3 & 11,2 & 21,7 & 19,0 & 10,7 \\
\hline & \multirow{2}{*}{3} & $\mathrm{~V}_{3}$ & 36,1 & 37,7 & 32,4 & 30,2 & 27,2 & 29,8 \\
\hline & & $\mathrm{V}_{4}$ & 21,0 & 14,0 & 11,0 & 23,4 & 20,1 & 2,6 \\
\hline \multirow{4}{*}{$\begin{array}{c}3 \\
\text { (диферен- } \\
\text { ційований) }\end{array}$} & \multirow[b]{2}{*}{0} & $\mathrm{~V}_{3}$ & 32,4 & 34,2 & 31,2 & 29,7 & 28,1 & 27,4 \\
\hline & & $\mathrm{V}_{4}$ & 22,1 & 16,0 & 11,9 & 23,2 & 19,1 & 14,7 \\
\hline & \multirow{2}{*}{3} & $\mathrm{~V}_{3}$ & 31,3 & 35,3 & 32,2 & 30,4 & 29,2 & 28,6 \\
\hline & & $\mathrm{V}_{4}$ & 25,5 & 16,1 & 11,6 & 24,5 & 20,9 & 14,3 \\
\hline \multirow{4}{*}{$\begin{array}{c}4 \\
\text { (тривалий } \\
\text { мілкий) }\end{array}$} & \multirow{2}{*}{0} & $\mathrm{~V}_{3}$ & 38,8 & 35,8 & 33,9 & 34,7 & 33,9 & 32,1 \\
\hline & & $\mathrm{V}_{4}$ & 18,4 & 17,7 & 14,7 & 19,3 & 18,3 & 15,7 \\
\hline & \multirow[b]{2}{*}{3} & $\mathrm{~V}_{3}$ & 39,7 & 36,2 & 35,5 & 35,9 & 34,4 & 33,1 \\
\hline & & $\mathrm{V}_{4}$ & 19,1 & 19,0 & 13,9 & 20,3 & 18,9 & 14,5 \\
\hline
\end{tabular}




\section{СІЛЬСЬКЕ ГОСПОДАРСТВО. РОСЛИННИЦТВО}

На дату збирання врожаю величина аерації шару грунту 10-20 см помітно не відрізняється по варіантах обробітку, а в шарі 20-30 см вона була за плоскорізного і диференційованого обробітку відповідно на 3,7 і 0,9 \% нижчою, ніж на контролі.

Помітне покращання структурного стану грунту 3 підвищенням рівня внесених добрив забезпечувало деяке зменшення об'ємної маси грунту і збільшення загальної пористості. Так, у середньому по досліду за внесення найвищої норми

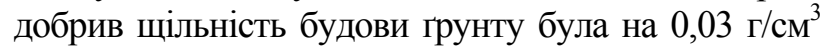
нижчою, а сумарний об'єм пор - на 1,5 \% вищим, порівняно 3 неудобреними ділянками.

Установлено, що проведення лише один раз за ротацію сівозміни глибокої оранки (4 варіант) усуває гетерогенність орного шару на 1,5-2 роки. На день збирання гороху уже чітко простежувалась диференціація орного шару чорнозему за вмістом рослинних решток, доступних форм

\section{БІБЛІОГРАФІЯ}

1. Адаптивні системи землеробства / [Гудзь В. П., Примак І. Д., Рибак М.Ф. та ін.] ; за ред. В. П. Гудзя. - К. : Центр учбової літератури, 2007. - С. 148-158, 200-216, 241-250, 284-292.

2. Мінімалізація механічного обробітку грунту при вирощуванні кукурудзи / [Єщенко В. О., Каричковський Д. Л., Каричковський В. Д., Сщенко О. В.] ; за ред. В. О. Сщенка. - Умань, 2007. $56 \mathrm{c}$.

3. Земледелие / [Баздырев Г. И., Лошаков В. Г., Пупонин А. И. и др.] ; под ред. А. И. Пупонина. М. : Колос, 2004. - С. 302-357.

4. Медведєв B. В. Грунтово-технологічні вимоги до грунтообробних знарядь і ходових систем машинно-тракторних агрегатів / В. В. Медведєв, Т. М. Лактіонова. - Х. : КП Друкарня № 13, 2008. -68 c.

5. Медведев B. В. Структура почвы (методы, генезис, классификация, эволюция, география, мониторинг, охрана) / В. В. Медведев. - Х. : издво «13 типография», 2008. - 406 с.

6. Примак I. Д. Історичні передумови застосування мінімізації механічного обробітку грунту в землеробстві України // Науковий вісник Національного аграрного університету : зб. наук. елементів живлення і агрономічно цінних агрегатів.

Продуктивність сівозміни за диференційованого і тривалого мілкого обробітку була на рівні контролю, а за плоскорізного - істотно нижчою. 3бір сухої речовини на 5-7 ц/га нижчий за другого варіанта обробітку, ніж контрольного.

Висновок. Постійний плоскорізний обробіток призводить до погіршення структурного стану орного шару грунту. Найбільш оструктуреним орний шар був у разі тривалого мілкого обробітку. Щільність нижньої частини орного шару істотно зростає за плоскорізного і диференційованого обробітку, порівняно 3 контролем. Об'ємна маса і загальна пористість орного шару помітно не відрізняється на ділянках тривалого полицевого і тривалого мілкого обробітку. Сумарний об'єм пор орного шару на 3-4 \% менший за плоскорізного і диференційованого, ніж тривалого полицевого обробітку.

праць / I. Д. Примак, О. С. Мудрук, О. І. Примак. К., 2005. - Вип. 80. - Ч. 2. - С. 74-81.

7. Примак I. Д., Примак О. I. Історичні передумови мінімізації механічного грунту // Вісник Білоцерківського державного аграрного університету : зб. наук. праць / I. Д. Примак, О. І. Примак. - Біла Церква, 2005. - Вип. 32. C. $130-140$.

8. Ресурсозберігаючі технології механічного обробітку грунту в сучасному землеробстві України / [Примак І. Д., Сщенко В. О., Манько Ю. П. та ін.] ; за ред. І. Д. Примака. - К. : КВІЦ, 2007. 272 c.

9. Результаты изучения элементов энергосберегающих технологий возделывания культур зерно-свекловичного севооборота / [Павловский В. Б., Василенко И. Д., Пчеленко Е. И. и др.] // Ресурсосберегающие технологии обработки почв : сб. науч. тр. ВНИИЗ и ЗПЭ. - Курск, 1989. - С. 147154.

10. Шикула Н. К., Назаренко Г. В. Минимальная обработка черноземов и воспроизводство их плодородия / Н. К. Шикула, Г. В. Назаренко. - М. : Агропромиздат, 1990. - 320 с. 